\title{
EDUKASI DAMPAK EKSPLOITASI DAN POTENSI PEMANFAATAN EKOSISTEM SUNGAI BAGI MASYARAKAT PENAMBANG PASIR ILEGAL DI DESA BELOTAN, BENDO, MAGETAN *
}

\author{
Asri Musandi Waraulia ${ }^{1}$, Pujiati $^{2}$, Sri Lestari ${ }^{3}$, \\ ${ }^{1)}$ Universitas PGRI Madiun, Madiun, Jawa Timur, Indonesia \\ ${ }^{2}$ Universitas PGRI Madiun, Madiun, Jawa Timur, Indonesia \\ ${ }^{3)}$ Universitas PGRI Madiun, Madiun, Jawa Timur, Indonesia \\ 1*Email: asrimusandi@unipma.ac.id \\ ${ }^{2}$ Email: pujiati@unipma.ac.id \\ ${ }^{3}$ Email: lestarisri@unipma.ac.id
}

\begin{abstract}
The mining industry adds the country's income and engage employment. In contrast, it also prones to environmental destruction. Many mining activities that invite the spotlight of the surrounding community due to environmental destruction, endanger the safety of the lives of miners, trigger natural disasters and also socio-economic problems. To reduce the number of sand miners, especially in Belotan village, Magetan, this partnership program was created with the aim of providing knowledge to the community about the importance of maintaining river ecosystems and the potential benefit from river ecosystems. The method used in this activity is a survey, giving an extension questionnaire about the importance of maintaining river ecosystems, monitoring and evaluation. Based on this program,it can be concluded that there was improvement of societies understanding related to: 1)the impact of illegal of sand mining and 2) how to exploit river properly. It is proven by more than $60 \%$ respondents agree with the usefulness of the material that has been presented and get new information about river potential in village area
\end{abstract}

\section{ABSTRAK}

Industri pertambangan selain mendatangkan devisa dan menyedot lapangan kerja juga rawan terhadap pengrusakan lingkungan. Banyak kegiatan penambangan yang mengundang sorotan masyarakat sekitarnya karena pengrusakan lingkungan, membahayakan keselamatan jiwa penambang, memicu terjadinya bencana alam dan juga masalah sosial ekonomi. Untuk mengurangi jumlah penambang pasir khususnya di desa Belotan, Magetan maka program kemitraan ini dibuat dengan tujuan memberikan pengetahuan kepada masyarakat tentang pentingnya menjaga ekosistem sungai dan potensi pemanfaatan ekosistem sungai yang baik dan benar. Metode yang dipakai dalam kegiatan ini adalah survey, pemberian kuisioner penyuluhan tentang pentingnya menjaga ekosistem sungai, monitoring dan evaluasi. Berdasarkan hasil kegiatan diketahui bahwa terjadi peningkatan mengenai pemahaman masyarakat mengenai dampak penambangan pasir secara ilegal dan peningkatan pemahaman masyarakat mengenai pemanfaatan sungai dengan baik dan benar. Hal ini dibuktikan dengan lebih dari $60 \%$ responden setuju dan mengetahui tentang kebermanfaatan materi yang disajikan dengan mendapatkan pengetahuan baru tentang potensi sungai di area desa.

Keywords: exploitation, river, ecosystem 


\section{PENDAHULUAN}

Industri pertambangan merupakan salah satu sektor yang menjanjikan bagi pemerintah Indonesia sebagai sumber devisa negara. Selain sebagai sumber devisa kegiatan pertambangan juga merupakan sektor industri yang membuka banyak lapangan kerja merupakan sumber Pendapatan Asli Daerah bagi kota maupun kabupaten. Kegiatan pertambangan meliputi suatu kegiatan yang terdiri dari eksplorasi, eksploitasi, pengolahan/ pemurnian, pengangkutan mineral/ bahan tambang. Di sisi lain Industri pertambangan juga rawan terhadap pengrusakan lingkungan. Banyak kegiatan penambangan yang mengundang sorotan masyarakat sekitarnya karena pengrusakan lingkungan, apalagi penambangan tanpa izin yang selain merusak lingkungan juga membahayakan jiwa penambang karena keterbatasan pengetahuan masyarakat penambang dan juga karena tidak adanya pengawasan dari dinas instansi terkait. Kondisi seperti ini terjadi di bantaran kali Gandong Kabupaten Magetan Propinsi Jawa Timur tepatnya di Desa Belotan.

Proses penambangan pasir secara berkelanjutan menimbulkan masalah dari banyak segi yang meliputi masalah ekologis, masalah fisik lingkungan dan masalah sosial Ekonomi Masyarakat. Permasalahan ekologis yang terjadi di desa ini meliputi peningkatan sedimentasi pasir di sungai Gandong, Terjadinya erosi pada lokasi penambangan pasir di Desa Belotan diikuti hilangnya bahan organik dan pemadatan tanah sehingga terjadi penurunan kapasitas infiltrasi tanah, perubahan struktur tanah menyebabkan terjadinya perubahan dari pori yang besar ke pori yang kecil sehingga kapasitas infiltrasi tanah menurun sehingga aliran air permukana menjadi lancer dan hal ini dapat menyebabkan terjadinya banjir. Pengaruh yang sistemik tersebut dapat memicu terjadinya erosi, tanah longsor, berkurangnya ketersediaan sumber air dan dapat memicu terpotongnya alur air tanah.
Dampak fisik yang terjadi akibat penambangan pasir ini meliputi hilangnya sebagian lapisan tanah karena proses pengambilan pasir, tanaman penutup tanah yang berfungsi sebagai pelindung tanah menjadi hilang sehingga produktivitas tanah menurun, rusaknya jalan di area sekitar pertambangan, terjadinya polusi udara yang dapat mengganggu kesehatan penambang dan warga sekitar.

Masalah sosial ekonomi yang terjadi pada masyarakat penambang pasir ilegal di desa Belotan meliputi potensi kecelakan kerja bahkan sampai terjadi kasus meninggal dunia akibat tertimbun runtuhan tanah sisa pertambangan. Proses penambangan yang ilegal ini menyebabkan tidak ada intansi penjamin terhadap semua kasus kecelakaan yang terjadi sehingga mereka harus menanggung semua beban biaya sendiri.

Berdasarkan permasalahan yang disampaikan diatas maka perlu dilakukan edukasi terkait dampak eksploitasi bahan tambang pasir dan batu di bantaran sungai khususnya sungai Gandong, dan sosialisasi mengenai potensi serta pemanfaatan sungai dan ekosistem daerah sungai secara baik dan benar.

\section{METODE PELAKSANAAN}

Kegiatan pengabdian ini dilakukan pada bulan Mei- Juni 2019 di Desa Belotan, Magetan, Jawa Timur. Bahan yang digunakan sebagai obyek kajian adalah masyarakat yang tinggal di area. Alat yang digunakan antara lain

daftar panduan pertanyaan, kuesioner, dan kamera. Alat yang digunakan dalam proses pengolahan data adalah seperangkat komputer dengan perangkat lunak Microsoft Office 2007 (Word, Excel). Jumlah responden dalam eduaksi ini adalah 28. Berikut adalah prosedur pelaksanaan pengabdian, yaitu:

1. Survey 
Dilakukan wawancara individual dengan responden dan menggunakan kuesioner terstruktur

2. Edukasi dampak eksploitasi bahan tambang pasir dan batu di bantaran sungai

3. Sosialisasi potensi dan pemanfaatan ekosistem sungai

4. Monitoring

Dilakukan untuk memantau proses aktivitas penambangan setelah dilakukan dilakukan edukasi.

5. Evaluasi

Evaluasi dilakukan dengan memberikan kuesioner setelah program dijalankan

Metode survey digunakan dalam teknik pengumpulan data. Metode survei ini menggunakan metode triangulasi yang meliputi kegiatan observasi, wawancara, dan daftar pertanyaan (Sugiyono, 2010)

\section{HASIL DAN PEMBAHASAN}

1. Sosialisasi dan edukasi terkait dampak eksploitasi pertambangan di daerah sungai

Pelaksanaan edukasi terkait dampak eksploitasi dan potensi pemanfaatan ekosistem sungai kepada masyarakat desa Belotan dilaksanakan pada 2 Mei 2019. Setelah dilaksanakan edukasi, masyarakat akan menjadi tahu dan sadar akan dampak eksploitasi sungai. Analisis data atas persepsi warga terhadap edukasi ini menggunakan data scoring yang dianalisis secara deskriptif kualitatif.

Sebelum pelaksanaan sosialisasi silakukan pretest terlebih dahulu mengenai pengetahuan dan pemahaman masyarakat terhadap dampak penambangan pasir secara ilegal dan secara kontinuitas serta pemahaman mengenai potensi pemanfaatan sungai secara baik dan benar. Berdasarkan hasil pre test di ketahui bahwa sebanyak $75 \%$ masyarakat yang hadir tidak mengetahui dampak penambangan pasir ilegal terhadap ekosistem sungai, sebanyak $64,3 \%$ masyarakat tidak mengetahui mengenai dampak penambangan pasir ilegal terhadap lingkungan sekitar, 71,4\% masyarakat tidak mengetahui dampak penambangan pasir ilegal terhadap kesehatan dan hanya 3,6\% masyarakat yang mengetahui pemanfaatan sungai dengan baik dan benar.

Data hasil post test menunjukkan bahwa terjadi peningkatan pemahaman yang signifikan terhadap pengetahuan yang diberikan. Hasil analisis menyebutkan bahwa sebanyak $60,7 \%$ masyarakat yang hadir sangat mengetahui dampak penambangan pasir ilegal terhadap ekosistem sungai, 57,1\% masyarakat sangat mengetahui dampak penambangan pasir ilegal terhadap lingkungan sekitar, sebanyak 67,9\% masyarakat sangat mengetahui dampak penambangan pasir ilegal terhadap kesehatan dan 50\% masyarakat memahami bagaimana pemanfaatan sungai dengan baik dan benar.

Dari hasil kualitas sosialisasi dianalisis berdasarkan persepsi masyarakat terhadap materi sosialisai yang di berikan. Hasil analisis menunjukkan bahwa rata-rata persepsi masyarakat tentang kejelasan penyampaian materi terkait edukasi dampak eksploitasi bahan tambang pasir disungai adalaah $82,2 \%$. Selanjutnya, $64,3 \%$ masyarakat setuju bahwa materi yang disampaikan cukup jelas. Kemudian, 53\% masyarakat merespon bahwa materi yang disampaikan penyaji sesuai dengan kondisi lingkungan. Terakhir tentang solusi yang dikemukakan terkait pemanfaatan ekosistem sungai bisa diterapkan, sejumlah $82,1 \%$ setuju. Berikut adalah hasil tabel hasil kuesioner yang diberikan kepada 28 responden. 
Tabel 1. Data hasil angket pengetahuan masyarakat sebelum dan setelah dilakukan edukasi pertambangan di sungai.

a. Pre test

\begin{tabular}{llcccc}
\hline \multirow{2}{*}{ No. } & \multicolumn{1}{c}{ Keterangan } & \multicolumn{3}{c}{ Jumlah Jawaban } \\
\cline { 3 - 5 } & $\begin{array}{c}\text { Tidak } \\
\text { Tahu }\end{array}$ & $\begin{array}{c}\text { Kurang } \\
\text { tahu }\end{array}$ & Tahu & $\begin{array}{c}\text { Sangat } \\
\text { Tahu }\end{array}$ \\
\hline 1. & $\begin{array}{l}\text { Pengetahuan mengenai dampak } \\
\text { penambangan pasir ilegal terhadap } \\
\text { ekosistem sungai }\end{array}$ & $75,0 \%$ & $17,9 \%$ & $7,1 \%$ & $0 \%$ \\
2. $\quad \begin{array}{l}\text { Pengetahuan mengenai dampak } \\
\text { penambangan pasir ilegal terhadap }\end{array}$ & $64,3 \%$ & $32,1 \%$ & $3,6 \%$ & $0 \%$ \\
$\quad \begin{array}{l}\text { lingkungan sekitar } \\
\text { 3. }\end{array}$ & $71,4 \%$ & $21,4 \%$ & $7,1 \%$ & $0 \%$ \\
$\quad \begin{array}{l}\text { Pengetahuan mengenai dampak } \\
\text { penambangan pasir ilegal terhadap } \\
\text { kesehatan } \\
\text { Pengetahuan mengenai pemanfaatan }\end{array}$ & $60,7 \%$ & $35,7 \%$ & $3,6 \%$ & $0 \%$ \\
\hline
\end{tabular}

b. Post test

\begin{tabular}{|c|c|c|c|c|c|}
\hline \multirow[b]{2}{*}{ No. } & \multirow[b]{2}{*}{ Keterangan } & \multicolumn{3}{|c|}{ Jumlah Jawaban } & \multirow[b]{2}{*}{$\begin{array}{c}\text { Sangat } \\
\text { Tahu }\end{array}$} \\
\hline & & $\begin{array}{l}\text { Tidak } \\
\text { Tahu }\end{array}$ & $\begin{array}{c}\text { Kurang } \\
\text { tahu }\end{array}$ & Tahu & \\
\hline 1. & $\begin{array}{l}\text { Pengetahuan mengenai dampak } \\
\text { penambangan pasir ilegal terhadap sungai }\end{array}$ & $0,0 \%$ & $0,0 \%$ & $39,3 \%$ & $60,7 \%$ \\
\hline 2. & $\begin{array}{l}\text { Pengetahuan mengenai dampak } \\
\text { penambangan pasir ilegal terhadap } \\
\text { lingkungan sekitar }\end{array}$ & $0,0 \%$ & $0,0 \%$ & $42,9 \%$ & $57,1 \%$ \\
\hline 3. & $\begin{array}{l}\text { Pengetahuan mengenai dampak } \\
\text { penambangan pasir ilegal terhadap } \\
\text { kesehatan }\end{array}$ & $0,0 \%$ & $3,6 \%$ & $28,6 \%$ & $67,9 \%$ \\
\hline 4. & $\begin{array}{l}\text { Pengetahuan mengenai pemanfaatan } \\
\text { sungai dengan baik dan benar }\end{array}$ & $0,0 \%$ & $3,6 \%$ & $50,0 \%$ & $46,4 \%$ \\
\hline
\end{tabular}

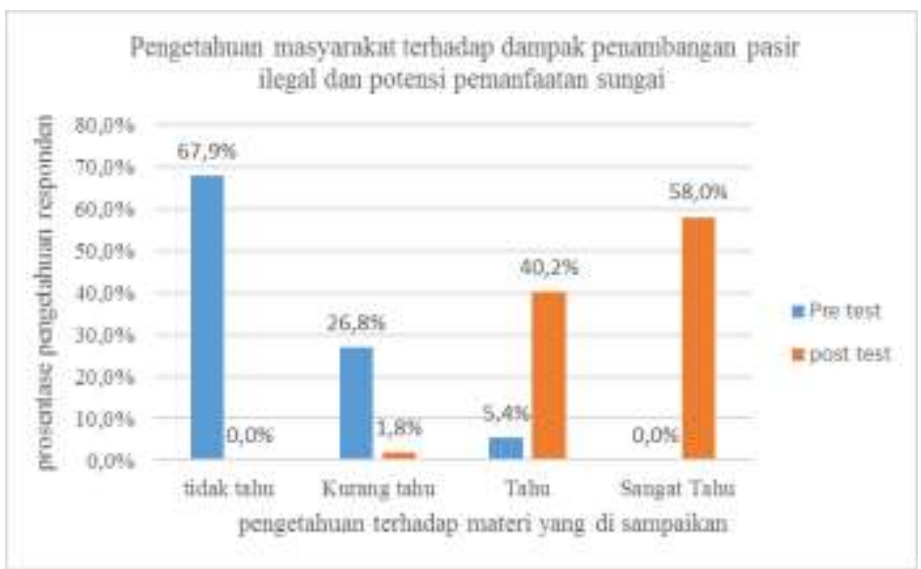

Gambar 1. Prosentase pemahaman masyarakat terhadap dampak eksploitasi sungai sebelum dan sesudah kegiatan edukasi 
Tabel 2 Kuesioner Edukasi Ekosistem

\begin{tabular}{clcccc}
\hline No & Pertanyaan & SS & S & KS & TS \\
\cline { 2 - 5 } 1 & Penyampaian materi tentang edukasi jelas & $17,8 \%$ & $82,2 \%$ & \\
\cline { 2 - 5 } 2 & Materi yang disampaikan bermanfaan & $64,3 \%$ & $35,7 \%$ & \\
\cline { 2 - 5 } 3 & Materi yang disampaikan sesuai dengan kondisi lingkungan & $53,6 \%$ & $46,4 \%$ & \\
\cline { 2 - 5 } & Solusi yang dikemukakan yang bisa diterapkan & $14,3 \%$ & $82,1 \%$ & $3,6 \%$ \\
\cline { 2 - 5 }
\end{tabular}
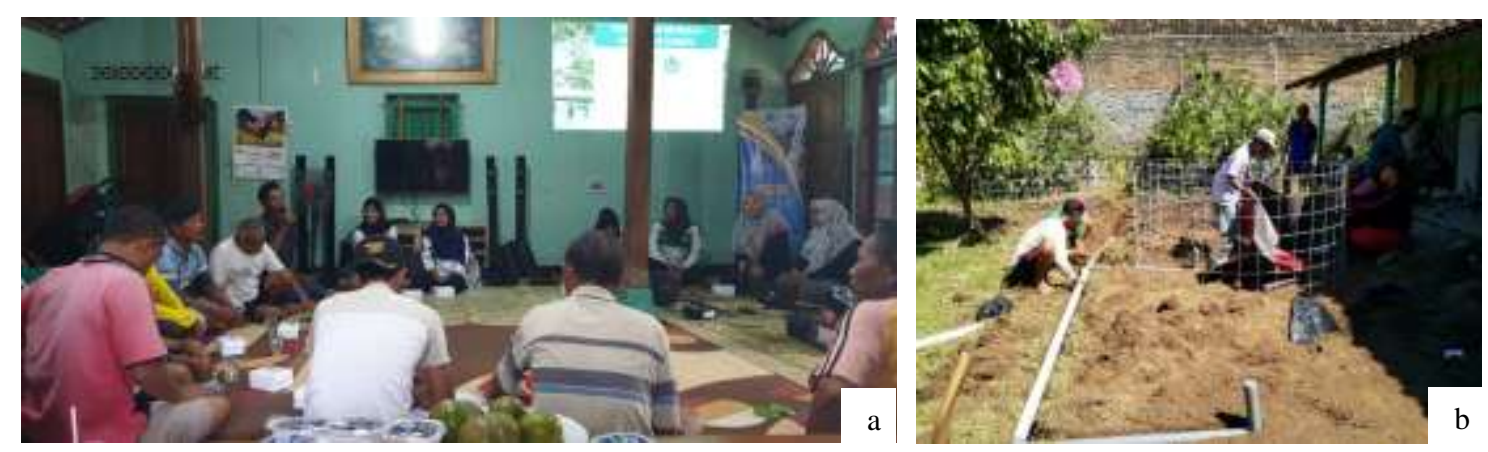

Gambar 2. Dokumentasi kegiatan di lapangan: a) proses kegiatan sosialisasi; b) kelompok penambang pasir yang memulai agribisnis perairan

Dari hasil kuesioner dapat disimpulkan bahwa respon masyarakat bagus terhadap edukasi yang telah diberikan oleh tim pengabdian. Hal tersebut dapat dilihat dari analisis kuisioner sebelum dan setelah dilakukan sosialisi dan edukasi.

Berdasarkan hasil monitoring dilapangan juga diketahui bahwa aktivitas penambangan yang terjadi dilapangan berkurang intensitasnya walaupun belum terlihat signifikan, beberapa masyarakat yang membutuhkan pasir sungai banyak yang langsung membeli ke toko bangunan ini menunjukkan bahwa stok pasir internal memang sudah berkurang, bahkan ada masyarakat tergerak untuk berpindah mata pencaharian seperti wiraswasta, beternak maupun budidaya perairan. Tim pelaksana juga memberikan edukasi mengenai pemanfaatan ekosistem sungai yang baik dan benar tanpa memberikan dampak buruk pada ekosistem sungai yang meliputi: pemanfaatan sungai menjadi objek wisata, pemanfaatan sungai untuk peternakan dan perikanan, dan potensi pemanfaatan sungai menjadi sumberdaya air untuk pembangkit listrik.
Berdasarkan semua permasalahan yang terjadi pada kelompok penambang pasir ilegal di desa Belotan, Magetan upaya pemberdayaan masyarakat memang harus dilakukan dan hal tersebut harus mendapatkan dukungan penuh oleh pemerintah desa khususnya serta pihak pihak terkait yang meliputi stakeholder kunci (pemerintah, selaku pihak pengambil keputusan), stakeholder primer (pihak yang mempunyai kepentingan langsung dengan program), dan stakeholder skunder (pendukung). Setelah dilakukan sosialisasi dan edukasi maka perlu juga dilakukan pemberdayaan sebagai upaya untuk melakukan perubahan sosial yang terencana untuk mengatasi permasalahan-permasalahan yang terjadi di masyarakat (Pujiati, 2017). 


\section{KESIMPULAN}

Berdasar pada uraian tersebut di atas maka simpulan yang dihasilkan dalam penelitian ini adalah sebagai berikut:

1. Telah terjadi penurunan fungsi hidrologis fungsi daerah aliran sungai akibat berbagai kegiatan masyarakat, yaitu: menambang pasir secara ilegal

2. Persepsi masyarakat terhadap edukasi tentang pelestarian alam dan pemanafaatan potensi sungai dalam kategori baik/tinggi.

\section{REFERENSI}

Sugiyono, 2010. Metode Penelitian Kuantitatif Kualitatif dan R\&D. Penerbit Alfabeta, Bandung

Odum, E.P. 1971. Fundamentals of Ecology. W.B. Saunders Company, London.

Manan, S. 1979. Pengaruh Hutan dan Managemen Daerah Aliran Sungai. Fakultas

Kehutanan, Institut Pertanian Bogor.

Pujiati, C.N Primiani, M.Lukitasari, D.R Sari. (2017). Aplikasi Pertanian Hemat Lahan Melalui Sistem Vertikultur Pada Petani Bawang Merah di Kecamatan Plaosan, Magetan. Seminar Nasional Hayati V. 5 (2017). 170-176

Jawa Timur

Ratnaningsih, Maria, 2008. Pengelolaan Daerah Aliran Sungai Cimanuk Terpadu Dengan Pendekatan Pembayaran Jasa Lingkungan. Disertasi, Program Studi Ilmu Lingkungan, Program Pascasarjana Universitas Indonesia. Jakarta. 